\title{
Professional Learning and Distributed Leadership: A Symbiotic Relationship
}

Rachel Denee

Victoria University of Wellington

Pedagogical improvement in early childhood education (ECE) is critically impacted by leadership and professional learning. Despite this importance, government funding for ECE professional learning has been significantly reduced over the past decade. Meanwhile, a growing body of research is suggesting that teacher professional learning is most effective when contextualised and sustained over time. In $E C E$, positional leaders have responsibility for ensuring ongoing teacher professional learning and the development of the programme while developing a culture of distributed leadership. This interpretive mixed-methods study examined the practices and perceptions of ECE teachers and leaders about leadership and professional learning. Surveys and interviews were designed to reveal the relationship between distributed leadership and professional learning in ECE settings and sought to discover practices of effective positional leaders in facilitating both. From the results of this study, it emerged that distributed leadership and professional learning are symbiotic and that ECE positional leaders need to develop certain leadership practices within their services in order to successfully foster both.

Keywords: Professional learning; distributed leadership; early childhood education

\section{Introduction}

Professional learning and leadership are two critical factors that impact on pedagogical improvement in New Zealand early childhood education (Education Review Office, 2016a). Over the past decade, government funding for ECE professional learning has been drastically reduced (Cherrington \& Thornton, 2013; Dalli, 2017). At the same time, research is building to show that teacher professional learning is most effective when situated and sustained within the educational context (Timperley, Wilson, Barrar, \& Fung, 2007). In this environment, the responsibility falls on head teachers and supervisors - positional leaders - to lead teachers' ongoing learning and curriculum development, with expectations from governing bodies that leadership is in some way distributed or shared (Education Council New Zealand, 2017; Education Review Office, 2016a; Ministry of Education, 2017). Education Council New Zealand (2018) has recently developed a leadership strategy which promises to prioritise leadership development for ECE leaders, but whether this results in funding and programmes is still to be seen. Currently, ECE positional leaders are offered little to no training or leadership development and are largely left to figure out for themselves what effective leadership practice for professional learning might look like (Clarkin-Phillips \& Morrison, 2018; Thornton, 2015; Weisz-Koves, 2011).

The interpretive mixed methods study this article is based on examined the intersection of leadership and professional learning in the ECE sector of New Zealand. More specifically, it focused on how distributed leadership operates within the sector and specific workplaces to achieve positive professional learning outcomes. Surveys and interviews were 
designed to reveal the relationship between distributed leadership and professional learning in ECE settings and sought to discover practices of effective positional leaders in facilitating both. A national survey was carried out to gain an overview of current practices and perceptions about distributed leadership and professional learning in ECE. Three perceived high-quality ECE services were then chosen for further data collection including interviews with leaders and teams, producing the qualitative data that are the main focus of this article. A review of literature, survey data and interview findings were analysed and formulated into a framework of effective leadership practice focused on supporting professional learning.

\section{Distributed leadership}

Distributed leadership is becoming an expectation in ECE, with the responsibility for enacting leadership devolved to every member of the learning community, not just those in positions of leadership (Education Council New Zealand, 2018). However, distributed leadership remains a varied and contested concept which requires further research to clarify what it means in practice in different contexts (Dieronitou, 2014). Harris (2013) defines distributed leadership by the shift away from a view of leadership as occurring in certain people, towards a view of leadership as something that occurs in practices. Harris argues that this shift makes leadership available to everyone. Spillane, Halverson, and Diamond (2004) describe distributed leadership as leadership that stretches across an organisation amongst all members of the group, occurring in the interactions between leaders, followers, and situation. These conceptions of leadership as distributed fit well with the collaborative nature of team teaching in ECE.

\section{Professional learning communities}

The concept of professional learning communities (PLCS) is used throughout this study as a lens to view leadership and learning in education settings. Hipp and Huffman (2010) define PLCs as "professional educators working collectively and purposefully to create and sustain a culture of learning for all students and adults" (p. 12). The practices required of ECE positional leaders mirror, in many regards, the leadership described in PLC literature, where, to use a musical metaphor, positional leaders are members of the choir but also conductors (Stoll, 2011; Thornton \& Cherrington, 2014). In this configuration, positional leaders practise distributed leadership to encourage autonomy, deeper learning, engagement, and the effective use of individual expertise (Clarkin-Phillips, 2011; Stoll, 2011). In addition, the shared teaching spaces and smaller teaching communities of many ECE services facilitate some of the requirements of PLCs, such as having shared personal practice and collective learning and application (Thornton \& Wansbrough, 2012).

\section{Professional learning versus professional development}

'Professional learning' is a term that appears to arise out of dissatisfaction over traditional forms of professional development. For proponents of professional learning, traditional professional development has a number of weaknesses. For example, professional development is characterised as a system where individuals leave their professional environments to learn about something in a one-off workshop from an expert (Vescio, Ross, 
\& Adams, 2008). Irrespective of the knowledge of the expert, deep learning is thwarted by the de-contextualisation of learning from the professional environment (Webster-Wright, 2009). In addition, learning is assumed to occur in individuals (those who attend a professional development workshop) rather than in the social processes that generate and deepen meaning. In summary, professional development lacks contextual meaning, learning transfer, and sustainable change (Watson \& Williams, 2011).

While professional learning strives to achieve the same goal, namely improved professional practice, it embeds learning within the professional context of the learners and requires learners to engage in professional dialogue, to inquire, research, and teach each other (Cherrington \& Thornton, 2013; Watson \& Williams, 2011). The aforesaid professional dialogue between teachers is more than simply exchanging information; such dialogue allows the coconstruction of new meaning and knowledge (Rinaldi, 2006). The embedding of learning pays heed to theory that learners get more out of learning that occurs within the context to which it is applied as it makes use of tacit knowledge (Webster-Wright, 2009). The processes of inquiry, research, and peer teaching draw on theories of active learning while also recognising that learning occurs in the social creation of meaning about the world we live in (Mitchell \& Cubey, 2003; Swim \& Isik-Ercan, 2013). Therefore, professional learning is posited as a sustainable and effective way of improving pedagogical outcomes in educational settings (Colmer, 2017).

Unsurprisingly, professional learning is a well-received concept in education, and ECE in New Zealand specifically (Cherrington \& Thornton, 2013; Grey, 2011). The contextual, active, and socio-cultural aspects of learning are emphasised in pedagogical literature over the model of didactic learning that many believe underpin traditional professional development. For example, Te Whāriki - He whāriki mātauranga mō ngā mokopuna o Aotearoa Early childhood curriculum explicitly draws on socio-cultural learning theories (Ministry of Education, 2017). In addition, the embedding of learning allows groups to focus on issues that relate directly to the community; this may result in stronger engagement and longer lasting learning (Hord, 1997; Webster-Wright, 2009).

\section{The relationship between distributed leadership and professional learning}

The benefits of distributed leadership in education have significant overlap with those of effective teacher professional learning: increased engagement; deeper learning; contextspecific learning; and improved pedagogical practices among teachers (Poekert, 2012). Further, the role of the positional leader in distributed leadership is described similarly to the leadership of PLCs, with commonalities including collaboration, relational trust, shared vision, supportive structures, and opportunities for leadership (Cherrington \& Thornton, 2013; Edwards, 2012; Stoll, 2011; Thornton \& Wansbrough, 2012). This cross-over of terms and concepts makes clear the relationship between the two constructs. This relationship is interpreted in different ways. Distributed leadership can be described as an element of professional learning (Timperley, 2008), particularly in PLC literature (e.g., Hipp \& Huffman, 2010). Conversely, professional learning can be seen as an effect or element of distributed leadership in research focused on leadership practice (e.g., Clarkin-Phillips, 2011). Moreover, Poekert (2012) acknowledges the symbiotic relationship between the two areas of practice, where professional learning builds leadership capability in teachers and distributed leadership leads to professional learning for teachers. Regardless of the perspective, the positive connection between the two elements is evident and has potential power for capacity-building in teachers in terms of both leadership and learning. 


\section{The positional leader within distributed leadership and professional learning}

Te Whāriki is clear about the role of the positional leader in teacher leadership development and team professional learning, stating that, "promoting and supporting the ongoing learning and development of kaiako is a key responsibility of educational leaders" (Ministry of Education, 2017 , p. 59). Colmer, Waniganayake, and Field $(2014,2015)$ have researched leadership of professional learning in ECE, and propose distributed leadership as the ideal environment for effective professional learning for teachers. They explain the importance of both positional and distributed leadership in ECE and choose to use the terms 'positional leaders' and 'informal leaders' to distinguish between these roles in their writing. The ECE positional leader is shown as a guiding influence, with the power and responsibility to bring out leadership in everyone for the purpose of professional learning and improved practice. Colmer et al. (2014, p. 105) argue that, "distributed leadership assists in creating professional learning environments where educators can debate, disagree and provide critical feedback to each other" (p. 105). Edwards (2012) agrees that distributed leadership provides a rich environment for improved professional learning, and also emphasises the role of the positional leader in distributing leadership in PLCs. Furthermore, Edwards points out that the role of the positional leader is challenging and complex when required to lead a group of leaders where the direction and focus of the learning are fluid and changeable depending on the group's co-construction. To this end, the positional leader's skills in building relational trust are important, as trust allows the PLC to develop smoothly and effectively (Marsh, 2015; Stoll, 2011; Thornton \& Cherrington, 2014). The importance of leadership for the success of PLCs is implicit within much of the PLC literature (Hord, 1997), but how this success relates specifically to the role of the positional leader is an area of research still in its infancy (Colmer et al., 2015; Marsh, 2015).

\section{The study}

This interpretive study was designed, implemented and analysed using a mixed methods approach, combining a quantitative survey with a qualitative case study. The study focused on exploring two interconnected research questions regarding the relationship between distributed leadership and professional learning in ECE settings, and the positional leader's role in facilitating distributed leadership for professional learning:

- How does distributed leadership contribute to teachers' professional learning in early childhood education settings?

- What is the positional leader's role in facilitating distributed leadership for professional learning?

A nationwide online survey of qualified ECE teachers was carried out to explore current practices and perceptions about leadership and professional learning in the New Zealand ECE sector. The survey was based on a tool designed by Huffman and Hipp (2010) which was previously adapted for the New Zealand ECE context by Thornton and Wansbrough in 2012. The survey was further adapted for this study by removing a section on relational trust and adding a section on distributed leadership for professional learning in order to narrow the focus of the survey for the research questions. The survey consisted of five sections of statements requiring a Likert-style response (collective learning and application; shared personal practice; 
shared and supportive leadership; supportive structural conditions; distributed leadership for professional learning), and space for optional qualitative comments on each section. Six hundred and thirty-one responses to the survey were included in data analysis; this number cannot be compared to the number of email invitations sent because the emails were sent to service providers and it is impossible to know how many individual responses came from each service. Survey data were analysed using descriptive statistics (Fraenkel, Wallen, \& Hyun, 1993) and thematic analysis of the qualitative responses (Silverman, 2017).

The case study examined the phenomenon of leadership for professional learning in ECE teams from one geographical location in New Zealand. The units of analysis included three ECE services, three individual positional leaders, and the teaching team members from each service - a community early education and care service, a privately-owned early education and care service and a kindergarten. Non-probabilistic purposeful-type sampling was used, which allows for an intentional study of a targeted population from which the most insight and understanding can be gained (Merriam, 1998). Recommendations from sector leaders were sought to find three high-quality services with high-performing leaders and teams to interview. Once recommendations were gathered, services were checked for quality in Education Review Office evaluative reports, and centres representative of different services (kindergarten, private early education and care, and community-based early education and care) were selected as participants. Ethical procedures were followed by the researcher to gain informed consent from the participants through initial phone calls, meetings, and the use of information and consent forms. The case study was conducted using semi-structured interviews, individually with the three positional leaders and as focus groups with each of the three teaching teams. The resulting qualitative data were analysed using inductive thematic analysis (Creswell, 2013) in a process of coding and re-coding the data (Merriam, 1998). Six key ideas were developed into the 'Distributed Leadership for Professional Learning' framework (see Figure 1).

Contextual features of each of the three services in the case study are detailed in Table 1:

Table 1: Contextual features of services interviewed

\begin{tabular}{|c|c|c|c|c|c|c|c|c|}
\hline $\begin{array}{l}\text { Service } \\
\text { code }\end{array}$ & Service type & $\begin{array}{l}\text { Positional } \\
\text { leader, } \\
\text { Years in } \\
\text { leadership } \\
\text { role }\end{array}$ & $\begin{array}{c}\text { Management } \\
\text { structure }\end{array}$ & $\begin{array}{c}\text { Number of } \\
\text { teachers and } \\
\text { number } \\
\text { qualified }\end{array}$ & $\begin{array}{l}\text { Licensed } \\
\text { for } \\
\text { number } \\
\text { of } \\
\text { children }\end{array}$ & $\begin{array}{l}\text { Licensed } \\
\text { for age } \\
\text { range }\end{array}$ & Location & $\begin{array}{c}\text { Decile } \\
\text { rating } \\
\text { of } \\
\text { nearest } \\
\text { school* }\end{array}$ \\
\hline Service A & Kindergarten & $\begin{array}{l}\text { Head } \\
\text { teacher, } \\
13 \text { years }\end{array}$ & $\begin{array}{l}\text { Kindergarten } \\
\text { association, } \\
\text { Senior } \\
\text { teacher }\end{array}$ & $\begin{array}{l}6 \text { teachers } \\
\text { All qualified }\end{array}$ & 40 & $0-5$ & $\begin{array}{l}\text { Small } \\
\text { town, } \\
\text { semi- } \\
\text { rural }\end{array}$ & 1 \\
\hline Service B & $\begin{array}{l}\text { Private early } \\
\text { childhood } \\
\text { centre }\end{array}$ & $\begin{array}{l}\text { Head } \\
\text { teacher, } \\
1 \text { year }\end{array}$ & $\begin{array}{l}\text { Two owners- } \\
\text { directors and } \\
\text { pedagogical } \\
\text { leader }\end{array}$ & $\begin{array}{l}10 \text { teachers } \\
8 \text { qualified } \\
2 \text { in-training }\end{array}$ & 30 & $0-5$ & $\begin{array}{l}\text { City } \\
\text { suburb }\end{array}$ & 9 \\
\hline Service C & $\begin{array}{l}\text { Community- } \\
\text { based early } \\
\text { childhood } \\
\text { centre }\end{array}$ & $\begin{array}{l}\text { Team } \\
\text { leader, } \\
11 \text { years }\end{array}$ & $\begin{array}{l}\text { Incorporated } \\
\text { society, } \\
\text { Parent } \\
\text { management } \\
\text { committee }\end{array}$ & $\begin{array}{l}6 \text { teachers, } \\
5 \text { qualified, } 1 \\
\text { in-training }\end{array}$ & 30 & $2-5$ & $\begin{array}{l}\text { City } \\
\text { suburb }\end{array}$ & 4 \\
\hline
\end{tabular}

- Decile ratings are a New Zealand Ministry of Education system to rate the socio-economic level of the families that a school serves, 1 being low socio-economic and 10 being high socio-economic, based on various socio-economic indicators (Ministry of Education, 2018). 
Quotes from participants included in the following findings and discussion section are attributed by role and service, anonymised in this article using the following codes in Table 2:

Table 2: Codes for quotes by role and service

\begin{tabular}{lccc}
\hline & Service A & Service B & Service C \\
\hline Positional leader & $\mathrm{PL}, \mathrm{A}$ & $\mathrm{PL}, \mathrm{B}$ & $\mathrm{PL}, \mathrm{C}$ \\
Teacher & $\mathrm{T}, \mathrm{A}$ & $\mathrm{T}, \mathrm{B}$ & $\mathrm{T}, \mathrm{C}$ \\
\hline
\end{tabular}

\section{Findings and discussion}

This case study examined the intersection between distributed leadership and professional learning in the context of ECE in New Zealand. After establishing a positive relationship between the two areas of practice through the literature and the survey, a set of interviews with high performing leaders and teams was coded and categorised. The resulting data highlighted the perceived benefits of distributed leadership for professional learning as well as the importance of the positional leader's role. These findings, along with the survey data and literature, have been used to construct a framework of the beneficial effects of distributed leadership on professional learning and of effective leadership practices (see Figure 1). The framework is intended to guide positional leaders in ECE in developing distributed leadership for professional learning, and to facilitate relevant discussions with teachers. For the purpose of this article, three elements of the framework are highlighted and discussed: inquiry and articulation of thinking; collaboration and dialogue; and mentoring and coaching. This discussion addresses the need for deeper understanding about professional learning that is contextually situated in ECE teams and workplaces, and leadership practices that effectively facilitate such learning.

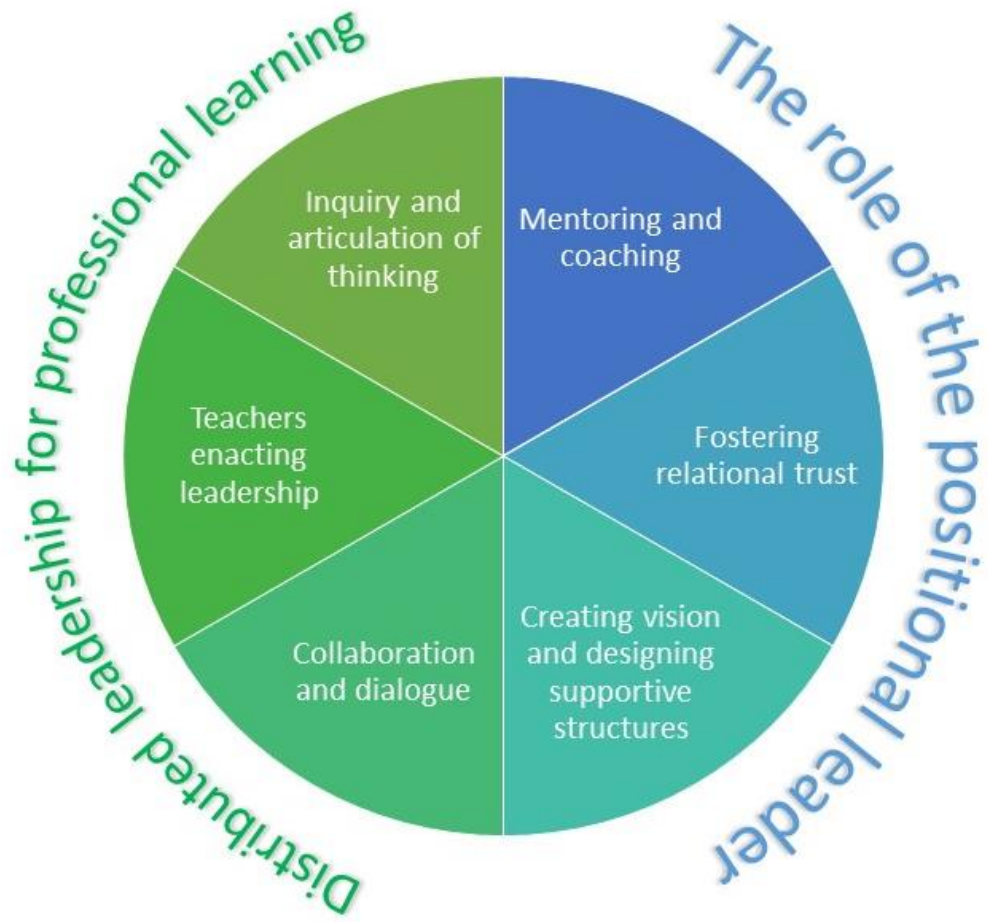

Figure 1. 'Distributed Leadership for Professional Learning' Framework 


\section{Distributed leadership for professional learning}

The first research question of the study asks, 'How does distributed leadership contribute to teachers' professional learning in early childhood education settings?' This question sought to understand the impact of a distributed leadership approach on teachers' professional learning in ECE teams. Two of the key ideas emerging from the framework above are discussed here: 'inquiry and articulation of thinking' and 'collaboration and dialogue'.

\section{Inquiry and articulation of thinking}

The teams and positional leaders interviewed described a pathway whereby teachers engaged in distributed leadership. The pathway involves teachers leading inquiry into practice and then articulating their ideas which can, ultimately, lead to changes in workplace practice. Teachers reported that they learned effectively when engaged in inquiry within their work context, and the professional learning was clarified and increased when they presented their thinking to others. This was evident in the interviews across all three teams; for example, one teacher stated that the "process of writing [a presentation] actually helps me grow as a teacher and become a lot more articulate in being able to explain to others ... why it is we do what we do," and that this process was "actually one of the biggest tools for deepening my own knowledge" $(T, C)$.

Teachers who saw themselves as leaders took responsibility for leading inquiry, initiating projects, and influencing change. Teachers were motivated to lead learning in areas of interest and were prompted by real challenges as they arose. The resulting professional learning was engaging and meaningful to the team. One teacher interviewed described how effective professional learning was designed and implemented within the specific context the team was working in:

It's relevant, it's what we want to learn about instead of someone else coming in and harping on about stuff that's not relevant, and within our team if someone's leading it they also know that there's challenges, and so we can nut our way around it, instead of coming away from the PD [professional development] somewhere else and going, "That was awesome but how's it going to work in my centre?" We make it work 'cause it's presented to us by people who know what our obstacles are. (T, C)

Teachers explained that they found professional learning engaging when it was led by one of the teaching team. The teacher who took a leadership role in an inquiry could act as a resource, and the team was able to come back to that person over time as questions arose. This process created genuine ongoing reflective learning similar to an action learning cycle, as practices were examined, new ways tried out and reflected upon, and further adjustments made. These benefits of distributed leadership for professional learning mirror claims about the benefits of PLCs as a whole (e.g., Hord, 1997; Stoll, 2011). Interestingly, though, it was both the teachers assuming leadership of a particular learning area as well as their colleagues who saw improved engagement, outcomes, and empowerment.

According to the teams interviewed, the teacher taking the lead in an area of inquiry often presented some of the research and thinking to others, usually to team members, and sometimes to parents or to professionals in the wider professional community. This aspect of leadership turned out to be a powerful learning experience for both the presenter and the 
audience. The most obvious learning here is that of the audience, who were receiving information and ideas as intentionally articulated by the presenter. The learning for the presenter was more surprising and somewhat hidden from immediate view. The presenter was required to develop thinking, ideas, and knowledge into a coherent format for presentation, which turned out to be a reflective learning process in itself. The teachers interviewed highlighted this aspect of their professional learning as a benefit and helpful process to concretise their learning, with one teacher saying that, "as teachers ... the biggest way of learning about something is to articulate it to your friends or to other people" (T, A). These ideas echo Poekert's (2012) claim that "teacher leadership leads to improved professional learning for colleagues and the teachers themselves" (p. 170). Similarly, Webster-Wright (2009) points to the centrality of active reflection within learning processes and, in a paraphrase of Kolb (1984, cited by Webster-Wright, 2009), includes the 'formulation of concepts' as part of this process. This 'formulation of concepts' is precisely what teachers described in their inquiry and preparation of professional learning.

The findings from this study suggest that inquiry and articulation complement one another in that together they improve engagement and relevance and enable sustainable learning. They also necessitate critical reflection and form an important outcome of distributed leadership within professional learning (Poekert, 2012). As such, these elements are a necessary part of a framework for the effective leadership of professional learning within New Zealand ECE.

\section{Collaboration and dialogue}

Teachers and positional leaders in this study highlighted collaboration and dialogue as essential to co-constructing new knowledge and sharing thinking in teaching teams. The interview data clearly linked distributed leadership to professional learning in that distributed leadership resulted in collaboration and dialogue, which led to improved teaching practice. During collaboration, teachers were able to support one another in the process of trying out new practices and could bring their various understandings together to create a stronger and more complex shared understanding than the understanding an individual teacher could likely develop alone. One teacher summarised the benefits of such collaboration, stating that "multiple voices are heard, people's strengths and passions are nurtured, and the capability of all is grown" (T, A). This statement fits well with Dooner, Mandzuk, and Clifton's (2008) succinct explanation of the process of teacher collaboration as, "drawing on each other's strengths to achieve a shared goal" (p. 565). Both the professional learning literature and the ECE literature in New Zealand focus on collaboration as a key feature of effective practice (e.g., Cherrington \& Thornton, 2013; Mitchell \& Cubey, 2003; Watson \& Williams, 2011) even where distributed leadership is not mentioned as a model.

Interview participants described professional dialogue as one of the most important arenas for professional learning, and proposed that dialogue was enhanced in a team environment where teachers acted as leaders. Professional dialogue could be scheduled in meeting times or take place in spontaneous conversation during each day, and both kinds of dialogue were seen as highly valuable to professional learning by the participants:

I think conversation is absolutely crucial when it comes to professional learning 'cause that's when you can be, you know, asking for advice or hearing someone else's perspective or point of view, or just maybe, you know, hearing something and thinking 
about it in a different way. And so that's how I think professional learning comes ... when your ideas are challenged or you think about things a different way, so having multiple opportunities for good conversation I think is crucial. (PL, B)

Distributed leadership in these teams was seen as resulting in professional, critical, and honest discussion which in turn results in professional learning for teachers. This culture of brave professional dialogue allowed team members to raise issues and question practices and habits, opening up inquiry into current and potential practices. As one teacher explained, "there's a little bit of debate, you kind of open each other's eyes to new perspectives and it's good ... not necessarily having to agree with each other ... it gives you room to think" $(T, B)$. Participants described enjoying the dynamics of constructive professional dialogue. This space to think and formulate new ideas resonates with Rinaldi's (2006) description of "an idea of dialogue not as an exchange but as a process of transformation," where the ending is unknown and possibilities are open (p. 184).

In summary, when teachers are given the opportunity to enact leadership, they are more likely to engage in collaboration and dialogue and to lead inquiry and articulate thinking in teams.

\section{The role of the positional leader}

The second research question of the study, 'What is the positional leader's role in facilitating distributed leadership for professional learning?' is addressed in this section. The key idea of 'mentoring and coaching' is highlighted, with further exploration of the leadership practices of scaffolding (Bruner, 1978) and the provision of resources and expertise as part of the ECE positional leader's role as mentor and coach. Additionally, the development of relational trust and vision are summarised, as these factors are also critical to the role of the positional leader acting within the 'Distributed Leadership for Professional Learning' framework to facilitate teachers' inquiry, collaboration, and dialogue in ECE settings.

\section{Mentoring and coaching}

Leadership practices related to mentoring and coaching most frequently raised in the interviews included facilitating goal setting, using questioning to provoke thinking, and providing adaptable levels of support depending on the teacher's stage in an area of learning. Clarkin-Phillips (2007) and Thornton (2015) argue that mentoring and coaching can help facilitate distributed leadership. The findings of this case study definitively support this statement. Importantly, the role of mentor or coach is not strictly one of expertise, but also requires the positional leader to be 'tuned in' to individual teachers' professional learning, as described by one positional leader interviewed:

If you've got those relationships with your teachers and you know who they are as teachers but also who they are as their own person, you can help and support and mentor them to be capable leaders in different aspects of their teaching careers. (PL, A)

Dembkowski, Eldridge, and Hunter (2006) describe mentoring and coaching as including questioning, analysis, reflection, and action. These elements are reminiscent of internal evaluation guidelines for education (Education Review Office, 2016b) and of action learning and 
teacher inquiry (Timperley et al., 2007). In addition, these elements reiterate the symbiotic relationship between mentoring and coaching and ECE professional learning and development.

Mentoring and coaching encompasses a broad range of practices that align with leadership practices in PLCs (Harrington, 2015; Thornton, 2015). Cherrington and Thornton (2013), Stoll (2011) and Thornton (2015) all highlight the value of an external influence in relation to mentoring and coaching. In ECE, rather than an external influence, it is more often the positional leader who will enact mentoring and coaching within the team (Rodd, 2013), for example, in facilitating teacher certification and appraisal processes. This case study demonstrated that effective positional leaders intentionally used mentoring and coaching strategies to develop teachers, and that the teachers were cognisant and appreciative of this approach. As Thornton (2015) argues, "effective ECE leaders mentor and coach their colleagues and encourage them to become involved in leadership" (p. 10). Moreover, the mentoring and coaching literature in education emphasises facilitating professional development (Murphy \& Thornton, 2015) is beneficial for positional leaders as well as teachers. Consequently, the ECE mentoring process can prove to be advantageous for both the mentor and the mentee (Harrington, 2015; Thornton, 2015), positioning mentoring and coaching practices as highly relevant to PLC leadership, to pedagogical leadership, and to ECE leadership. Mentors are simultaneously leaders and learners, truly members of learning communities as well as enacting distinct leadership roles, including scaffolding and providing resources and expertise as are examined in more detail below.

\section{Scaffolding}

Scaffolding, originally conceived by Bruner (1978) to describe the process of a parent, teacher or more experienced other providing support to a learner and then incrementally removing that support as the learner becomes more competent, is a familiar concept in ECE in New Zealand (Cherrington, 2018). Teachers in this study highlighted scaffolding as an effective strategy used by positional leaders to support leadership development and professional learning. To this end, positional leaders offered a higher level of support when needed and gradually reduced involvement as the teachers increased their own knowledge and leadership skills. One participant explained how scaffolding was being adapted to teachers' varying levels of knowledge, skills and experience whereby a positional leader:

...senses somebody needed some support to do that, where she scaffolded people and
really encouraged and supported people in that role so that everybody actually can grow
their capabilities and their sense of achievement, and I think that that showed a great
sense of atunement to looking at each person and nurturing those individual journeys
for each of us. (T, A)

Teachers described their positional leaders as providing opportunities for leadership, "where you get some responsibility, you're given some responsibility or take on some responsibility" $(T, B)$, and they appreciate the support of being "nurtured a bit, you know until you kind of find your feet and get up and on with it" (T, B). In summary, scaffolding was described as a flexible leadership approach, where the leader was at times more active and then gradually less active in supporting the developing leader. 


\section{Providing resources and expertise}

Teachers and positional leaders talked about the positional leader's role in supporting teacher inquiry, for example, by finding academic articles and offering advice and guidance, and by providing time, space, and sometimes funding to support professional learning and leadership. This supportive strategy for leadership development was used when teachers were attempting to lead an initiative for the first time, and they relied on the positional leader to provide resources and expertise in order to overcome challenges. Positional leaders were intentional about providing resources and expertise, for example, by contributing research to add depth to team professional dialogue and learning. One positional leader explained that she would prepare for team meetings by thinking about whether there were "things that teachers are not too clear on," then she would intentionally "do a bit of research around that topic and then give them that information." (PL, A)

The positional leader's practice of providing resources and expertise was purposeful, and clearly valued by teachers working in a distributed leadership environment, one teacher saying that the "time that we spend talking and learning from [the positional leaders] is priceless" ( $T, C)$.

\section{Trust and vision}

In addition to mentoring and coaching, two other elements of the role of the positional leader were found in this study to be important to distributed leadership and professional learning: fostering relational trust and creating vision and designing supportive structures. These key ideas have been highlighted in previous articles resulting from the study (Denee \& Thornton, 2017,2018 ) but demand a mention here as they are integral to leadership for learning in ECE. Interestingly, as mentioned above, the relational trust section was removed from the nationwide survey in the first phase of this research but emerged with such strength in the interview data that relational trust became one of the key ideas in the framework. This result supports Wahlstrom and Louis' (2008) finding that trust is integral to the positional leader's role in supporting teachers' pedagogical improvement. In this study the positional leaders, in the teams interviewed, were perceived as having responsibility for building a foundation of relational trust and maintaining the overarching vision to ensure team members were moving in the same direction. One positional leader interviewed emphasised:

Relationships are absolutely the foundation of anything that's going to happen in a positive fashion so I think by promoting really good open, positive, respectful and reciprocal relationships with your teaching team then you should be able to enable leadership, you know, where potential lies. (PL, B)

In these teams, the positional leader's responsibility for maintaining an overview also included the provision of supportive structures such as systems and resources to support teacher leadership development and professional learning. The ongoing visionary role of the positional leader was illustrated by one teacher who used the metaphor of a river to represent the team's professional learning journey, explaining that the positional leader provides the structure to guide the river's direction as it flows $(T, A)$. 


\section{Limitations and recommendations for further research}

The research reported on in this article was conducted on a small scale in one geographical region of New Zealand and is presented as an analysis of examples of effective practice rather than intended as a representation of practices across the country. While the three services were diverse in type and in management structure, they were all supported by management to engage in professional learning. It should be noted that many ECE services struggle to access non-contact time, meeting time, and funds for professional learning, and this has reportedly worsened since the 2009 government funding cuts to ECE in New Zealand (Dalli, 2017). With higher levels of untrained staff and less funding for professional learning, the past decade has been a challenge for ECE leaders and teachers to develop as professional learning communities. The Early Learning Strategic Plan (Ministry of Education, 2018), in development at the time of writing this article, offers a political glimmer of hope to the sector for improvement in these areas.

From the survey and interview data in this study and from the associated literature it is clear that distributed leadership offers the potential to foster professional learning in ECE teams. When teachers are empowered to participate in leadership, the entire learning community benefits from a kind of educational synergy, that is, together we are more than the sum of our individual strengths. The role of the positional leader has been shown to be critical to the development of distributed leadership and situated professional learning, and yet positional leaders in ECE are offered little guidance or support to develop leadership skills such as mentoring and coaching. In order for the youngest citizens of today to benefit from highly functioning professional teaching teams, investment in leadership development is needed as highlighted through the findings of this study.

The researcher recommends further research, as follows:

- Exploring professional learning approaches to develop ECE positional leaders' pedagogical leadership, in particular to develop skills for mentoring and coaching teachers;

- Investigation of mentoring and coaching as a leadership development tool for positional leaders in ECE; and

- Examining the role of teacher leadership in facilitating team professional learning in ECE settings.

\section{Conclusion}

The symbiotic relationship between distributed leadership and professional learning for teachers has been highlighted through this study. The practices of a small number of highly functioning leaders and teams were examined to understand the myriad ways that distributed leadership can be enacted to promote professional learning as well as the role of the positional leader in fostering distributed leadership and professional learning. The inclusion of different service types in the study - a community early education and care service, a privately owned early education and care service, and a kindergarten demonstrates that distributed leadership and professional learning practices can be exemplary across a variety of settings common in the New Zealand ECE sector. Similarities between the various teams and positional leaders interviewed also brought to light commonalities in the approaches of positional leaders despite their different contexts. 
Teachers, when given opportunities to enact leadership, lead and participate in inquiry, learn through articulation of thinking, and engage in collaboration and dialogue to achieve improved professional learning outcomes. Effective positional leaders utilise mentoring and coaching strategies to develop their team, while establishing a foundation of relational trust and providing oversight and vision to teachers' professional learning and development. The 'Distributed Leadership for Professional Learning' framework of effective leadership practices is intended to provide guidance to those in positions of leadership in ECE, a group that has traditionally been unsupported in terms of practical guidance and targeted professional learning. The researcher's intention is that this study will provide an impetus towards further support and leadership development programmes focusing on pedagogical improvement for ECE positional leaders and teachers.

\section{References}

Bruner, J. (1978). The role of dialogue in language acquisition. In A. Sinclair, R. Jarvella, \& W. Levelt (Eds.), The child's conception of language (pp. 241-256). New York: Springer-Verlag.

Cherrington, S. (2018). Early childhood teachers' thinking and reflection: A model of current practice in New Zealand. Early Years, 38(3), 316-332.

doi.org/10.1080/09575146.2016.1259211

Cherrington, S., \& Thornton, K. (2013). Continuing professional development in early childhood education in New Zealand. Early Years, 33(2), 119-132. doi.org/10.1080/09575146.2013.763770

Clarkin-Phillips, J. (2007). Distributing the leadership: A case study of professional development. (Masters thesis), The University of Waikato, Hamilton.

Clarkin-Phillips, J. (2011). Distributed leadership: Growing strong communities of practice in early childhood centres. Journal of Educational Leadership, Policy and Practice, 26(2), 14.

Clarkin-Phillips, J., \& Morrison, M. (2018). Leading in the early years: Who leads and how? Journal of Educational Leadership, Policy and Practice, 33(1), 1.

Colmer, K. (2017). Collaborative professional learning: Contributing to the growth of leadership, professional identity and professionalism. European Early Childhood Education Research Journal, 25(3), 436-449. doi.org/10.1080/1350293X.2017.1308167

Colmer, K., Waniganayake, M., \& Field, L. (2014). Leading professional learning in Early Childhood centres: Who are the educational leaders? Australasian Journal of Early Childhood, 39(4), 103.

Colmer, K., Waniganayake, M., \& Field, L. (2015). Implementing curriculum reform: Insights into how Australian early childhood directors view professional development and learning. Professional Development in Education, 41(2), 203-221. doi.org/10.1080/19415257.2014.986815

Creswell, J. (2013). Qualitative inquiry and research design: Choosing among five approaches. London: Sage.

Dalli, C. (2017). Tensions and challenges in professional practice with under-threes: A New Zealand reflection on early childhood professionalism as a systemic phenomenon. In 
E. J. White \& C. Dalli (Eds.), Under-three year olds in policy and practice (pp. 115129). Singapore: Springer.

Dembkowski, S., Eldridge, F., \& Hunter, I. (2006). The seven steps of effective coaching. London: Thorogood.

Denee, R., \& Thornton, K. (2017). Effective leadership practices leading to distributed leadership. Journal of Educational Leadership, Policy and Practice, 32(2), 33.

Denee, R., \& Thornton, K. (2018). Distributed leadership in ECE: Perceptions and practices. Early Years, 1-16. 10.1080/09575146.2018.1539702

Dieronitou, I. (2014). Unveiling the restricted and extended possibilities of distributed leadership. Researchers World, 5(1), 37.

Dooner, A.-M., Mandzuk, D., \& Clifton, R. (2008). Stages of collaboration and the realities of professional learning communities. Teaching and Teacher Education, 24(3), 564-574. doi.org/10.1016/j.tate.2007.09.009

Education Council New Zealand. (2017). Our code, our standards. Wellington: Author.

Education Council New Zealand. (2018). The leadership strategy for the teaching profession of Aotearoa New Zealand. Wellington: Author.

Education Review Office. (2016a). Early learning curriculum: What's important and what works. Wellington: Author.

Education Review Office. (2016b). Effective internal evaluation for improvement. Wellington: Author.

Edwards, F. (2012). Learning communities for curriculum change: Key factors in an educational change process in New Zealand. Professional Development in Education, 38(1), 25-47. doi.org/10.1080/19415257.2011.592077

Fraenkel, J., Wallen, N., \& Hyun, H. (1993). How to design and evaluate research in education (Vol. 7). New York: McGraw-Hill.

Grey, A. (2011). Professional dialogue as professional learning. New Zealand Journal of Teachers' Work, 8(1), 21-32.

Harrington, C. (2015). Awakening beginning teachers' passion through mentoring. In C Murphy \& K. Thornton (Eds.), Mentoring in early childhood education: A compilation of thinking, pedagogy and practice (pp. 1-13). Wellington: NZCER Press.

Harris, A. (2013). Distributed school leadership: Developing tomorrow's leaders. London: Routledge.

Hipp, K., \& Huffman, J. (2010). Demystifying the concept of professional learning communities. In K. Hipp \& J. Huffman (Eds.), Demystifying professional learning communities: School leadership at its best (pp. 11-21). Plymouth: Rowman \& Littlefield Education.

Hord, S. (1997). Professional learning communities: Communities of continuous inquiry and improvement. Austin, TX: Southwest Education Development Laboratory.

Huffman, J., \& Hipp, K. (2010). Diagnostic and planning tools. In K. Hipp \& J. Huffman (Eds.), Demystifying professional learning communities. School leadership at its best (pp. 43-56). Plymouth, UK: Rowman \& Littlefield Education.

Marsh, S. (2015). A model for leadership that improves learning: New insights for schools and scholars. Leadership and Policy in Schools, 14(1), 67-103. doi.org/10.1080/15700763.2014.983132

Merriam, S. (1998). Qualitative research and case study applications in education. . San Francisco: Jossey-Bass. 
Ministry of Education. (2017). Te Whāriki: He whāriki mātauranga mō ngā mokopuna o Aotearoa: Early childhood curriculum. Wellington: Author.

Ministry of Education. (2018). Early learning strategic plan. Retrieved from https://www.education.govt.nz/ministry-of-education/consultations-andreviews/early-learning-strategic-plan/

Mitchell, L., \& Cubey, P. (2003). Characteristics of professional development linked to enhanced pedagogy and children's learning in early childhood settings: Best evidence synthesis. Wellington: Ministry of Education.

Murphy, C., \& Thornton, K. (Eds.). (2015). Mentoring in early childhood education: A compilation of thinking, pedagogy and practice. Wellington: NZCER Press.

Poekert, P. E. (2012). Teacher leadership and professional development: Examining links between two concepts central to school improvement. Professional Development in Education, 38(2), 169-188. doi.org/10.1080/19415257.2012.657824

Rinaldi, C. (2006). In dialogue with Carlina Rinaldi: A discussion between Carlina Rinaldi, Gunilla Dahlberg and Peter Moss. In C. Rinaldi (Ed.), In dialogue with Reggio Emilia: Listening, researching and learning (pp. 178-195). London: Routledge.

Rodd, J. (2013). Leadership in early childhood (4 ${ }^{\text {th }}$ ed.). Sydney, Australia: Allen \& Unwin.

Silverman, D. (2017). Doing qualitative research: A practical handbook (5 $5^{\text {th }}$ ed.). London: Sage.

Spillane, J. P., Halverson, R., \& Diamond, J. B. (2004). Towards a theory of leadership practice: A distributed perspective. Journal of Curriculum Studies, 36(1), 3-34. doi.org/10.1080/0022027032000106726

Stoll, L. (2011). Leading professional learning communities. In J. Roberston \& H. Timperley (Eds.), Leadership and learning (pp. 103-117). Los Angeles: Sage. doi.org/10.4135/9781446288931.n8

Swim, T. J., \& Isik-Ercan, Z. (2013). Dispositional development as a form of continuous professional development: Centre-based reflective practices with teachers of (very) young children. Early Years, 33(2), 172-185. doi.org/10.1080/09575146.2012.753870

Thornton, K. (2015). The impact of mentoring on leadership capacity and professional learning. In C. Murphy \& K. Thornton (Eds.), Mentoring in early childhood education: A compilation of thinking, pedagogy and practice (pp. 1-13). Wellington: NZCER Press.

Thornton, K., \& Cherrington, S. (2014). Leadership in professional learning communities. Australasian Journal of Early Childhood, 39(3), 94.

Thornton, K., \& Wansbrough, D. (2012). Professional learning communities in early childhood education. Journal of Educational Leadership, Policy and Practice, 27(2), 51.

Timperley, H. (2008). Teacher professional learning and development. Brussels: International Academy of Education.

Timperley, H., Wilson, A., Barrar, H., \& Fung, I. (2007). Teacher professional learning and development: Best evidence synthesis iteration. Wellington: Ministry of Education.

Vescio, V., Ross, D., \& Adams, A. (2008). A review of research on the impact of professional learning communities on teaching practice and student learning. Teaching and Teacher Education, 24(1), 80-91. doi.org/10.1016/j.tate.2007.01.004

Wahlstrom, K. L., \& Louis, K. S. (2008). How teachers experience principal leadership: The roles of professional community, trust, efficacy, and shared responsibility. 
Educational Administration Quarterly, 44(4), 458-495.

doi.org/10.1177/0013161X08321502

Watson, B., \& Williams, B. (2011). Leadership: Leveraging the benefits of professional learning. Early Education, 50, 22.

Webster-Wright, A. (2009). Reframing professional development through understanding authentic professional learning. Review of Educational Research, 79(2), 702-739. doi.org/10.3102/0034654308330970

Weisz-Koves, T. (2011). Developing teacher leadership in early childhood education in Aotearoa through a potential-based approach. Journal of Educational Leadership, Policy and Practice, 26(2), 35.

Rachel Denee has been working in teaching, leadership, and research roles in early childhood education since 2000. Her research interests include educational leadership, professional learning, and visual art in early childhood. Rachel is a PhD candidate at Victoria University of Wellington, studying ECE teachers' practices and perceptions about art through a professional learning community.

Email: rachel.denee@vuw.ac.nz

ORCiD ID: 0000-0002-9508-6083 